\title{
EKSTRAKSI KALSIUM DARI BIJIH DOLOMIT TERKALSINASI MENGGUNAKAN PELARUTAN ASAM KLORIDA
}

\author{
Extraction of Calcium from Calcined Dolomite Ore Using \\ Hydrochloric Acid Leaching
}

\author{
AHMAD ROYANI dan RUDI SUBAGJA \\ Pusat Penelitian Metalurgi dan Material - LIPI \\ Gedung 470 Kawasan Puspiptek - Tangerang Selatan 15314, Indonesia \\ e-mail : ahmad.royani@lipi.go.id
}

\begin{abstract}
ABSTRAK
Penggunaan kalsium sangat luas dalam berbagai aplikasi sektor industri. Dolomit merupakan salah satu sumber penghasil kalsium selain batu kapur dan air laut. Ekstraksi kalsium dari mineral dolomit dapat dilakukan melalui proses pelarutan. Pada penelitian ini, dilakukan proses pelarutan dolomit menggunakan larutan asam klorida untuk mengekstrak kalsium. Pelarutan dilakukan dengan memvariasikan kecepatan pengadukan, konsentrasi asam, suhu proses dan rasio padatan terhadap larutan untuk setiap waktu proses 0,5; $1 ; 2 ; 3 ; 4$ dan 5 jam. Setelah proses pelarutan pada waktu tertentu sejumlah larutan diambil dengan menggunakan pipet sebanyak $5 \mathrm{~mL}$ kemudian disaring dan dianalisis menggunakan ICP-OES. Hasil percobaan menunjukkan bahwa efisiensi kalsium $\left(\mathrm{CaCl}_{2}\right)$ terekstrak meningkat dengan penambahan konsentrasi asam, rasio cairan/padatan dan peningkatan suhu. Hasil optimum dicapai pada suhu $75{ }^{\circ} \mathrm{C}$, konsentrasi larutan $2 \mathrm{M}$ $\mathrm{HCl}$ dan kecepatan pengadukan $400 \mathrm{rpm}$ dengan efisiensi kalsium terekstrak sebesar 97,57 \%.
\end{abstract}

Kata kunci: ekstraksi, asam klorida, dolomit, pelarutan.

\begin{abstract}
Calcium is widely used in a variety of industrial sector applications. Dolomite is one source of calcium besides limestone and seawater. The extraction of calcium from dolomite minerals can be done by the leaching process. In this work, the leaching of dolomite to extract calcium by hydrochloric acid was investigated. The effects of the stirring speed, acid concentration, reaction temperature and liquid-solid ratio for each reaction time of $0.5 ; 1 ; 2 ; 3 ; 4$ and 5 hours on the leaching have been evaluated. From the leaching solution, amount of the sample $(5 \mathrm{~mL})$ was taken out of the reactor and then filtered and analyzed by ICP OES. The experimental results show that the efficiency of calcium $\left(\mathrm{CaCl}_{2}\right)$ extracted increases with the addition of acid concentration, fluid/solid ratio, and increasing temperature. The optimum results were achieved at $75{ }^{\circ} \mathrm{C}$, the acid concentration of $2 \mathrm{M} \mathrm{HCl}$ and stirring speed of $400 \mathrm{rpm}$ with the efficiency of calcium extracted of $97.57 \%$.
\end{abstract}

Keywords: extraction, hydrochloric acid, dolomite, leaching.

\section{PENDAHULUAN}

Kalsium banyak digunakan dalam berbagai keperluan industri. Kalsium digunakan sebagai reduktan, deoksidisasi, desulfurisasi pada industri manufaktur. Kalsium juga digunakan dalam pembuatan semen dan mortar yang digunakan dalam konstruksi. 
Kalsium tidak pernah ditemukan di alam tanpa terkombinasi dengan unsur lainnya. Kalsium banyak terdapat sebagai batu kapur, gipsum, fluorit dan dolomit.

Mineral dolomit merupakan salah satu sumber penghasil logam kalsium selain batu kapur $\left(\mathrm{CaCO}_{3}\right)$ dan air laut. Dolomit mempunyai rumus kimia $\mathrm{Ca} \cdot \mathrm{Mg}\left(\mathrm{CO}_{3}\right)_{2}$, pada umumnya menunjukkan kenampakan warna putih namun demikian ada juga yang berwarna keabu-abuan, kebiruan dan warna kuning muda. Memiliki berat jenis antara 2,8 - 2,9 g/ $\mathrm{mL}$ dan bersifat lunak (derajat kekerasan hanya 3,5 - 4 skala mohr) dan mudah menyerap air (Mustafa, Al-Dahan dan Khachik, 2014; Xie $d k k ., 2016)$. Potensi dolomit di Indonesia cukup besar mulai dari propinsi Aceh hingga Papua dengan spesifikasi yang berbeda-beda. Penyebaran dolomit yang cukup besar terdapat di Propinsi Sumatera Utara, Sumatera Barat, Jawa Tengah, Jawa Timur Madura dan Papua (Erskini, 1996). Pemanfaatan mineral dolomit yang terdapat di Indonesia hanya sebatas untuk keperluan pembuatan pupuk dolomit dan bata dolomit untuk keperluan bahan bangunan.

Banyak penelitian mengenai pengolahan jenis mineral dolomit dengan berbagai metode yang telah dilakukan. Proses pengolahan dolomit dalam industri pada umumnya melalui jalur proses dekomposisi termal yang menghasilkan kalsin (CaO). Sedangkan proses pengolahan dolomit melalui pelarutan masih jarang dilakukan (Bayrak, Laçin dan Saraç, 2010; Raza, Zafar dan Najam-ul-Haq, 2013, 2014; Raza dkk., 2015; Royani, 2016). Raza dkk. (2015) telah melakukan studi tentang pelarutan bijih magnesit alam menggunakan asam suksinat sebagai agen pelarut. Hasil penelitiannya menunjukkan bahwa ekstraksi magnesium bergantung pada konsentrasi asam, temperatur reaksi, ukuran partikel bijih, kecepatan pengadukan dan rasio padatan. Pendekatan grafis dan statistik dalam analisis data kinetika menyatakan bahwa laju ekstraksi magnesium-kalsium dari magnesit alami dikendalikan oleh tahapan reaksi kimia. Energi aktivasi yang didapat dalam percobaan pelarutan magnesit ini sebesar $45,197 \mathrm{~kJ} \mathrm{~mol}^{-1}$ pada rentang suhu reaksi 40 ${ }^{\circ} \mathrm{C}$ sampai $70{ }^{\circ} \mathrm{C}$.
Pelarutan bijih dolomit Nigeria telah berhasil dilakukan dengan menggunakan pelarutan asam klorida pada suhu $27^{\circ} \mathrm{C}$ hingga $80{ }^{\circ} \mathrm{C}$ (Baba $d k k ., 2014)$. Kondisi optimum dicapai pada suhu $80{ }^{\circ} \mathrm{C}$, konsentrasi asam $2 \mathrm{~mol} / \mathrm{L}$ selama 120 menit pada ukuran partikel 0,01 $\mathrm{mm}$ dengan nilai efisiensi pelarutan sebesar 99,3 \%. Penentuan kinetika pelarutan dolomit didasarkan pada pendekatan Model Shrinking Core Model dan Simple Linear Regression Model menyatakan bahwa laju pelarutan dikendalikan oleh proses difusi.

Larutan asam juga telah digunakan dalam penelitian pemurnian bijih talk. Penelitiannya difokuskan untuk mengetahui pengaruh dari konsentrasi asam, suhu reaksi dan ukuran partikel. Hasil penelitian tersebut menyatakan bahwa kinetika kelarutan bijih talk dalam asam klorida $(\mathrm{HCl})$ meningkat dengan meningkatnya konsentrasi asam, suhu dan penurunan diameter partikel bijih. Dalam eksperimennya pada $75{ }^{\circ} \mathrm{C}$ dengan konsentrasi $2 \mathrm{~mol} / \mathrm{L} \mathrm{HCl}$ selama 120 menit, keterlarutan bijih mencapai 62,1\%. Energi aktivasi yang didapatkan pada percobaan ini sebesar 31,2 kJ mol-1 dan reaksi dikendalikan oleh laju difusi (Orosco $d k k$., 2011).

Pelarutan asam klorida juga telah digunakan untuk memisahkan kalsium dan magnesium dalam pembuatan nanopartikel $\mathrm{MgO}$ dari mineral dolomit melalui tahapan kalsinasi, pelarutan dan presipitasi (Mantilaka $d k k$., 2014). Asam klorida juga digunakan dalam penelitian pelarutan bijih dolomit-talk untuk mendapatkan larutan $\mathrm{MgCl}_{2}-\mathrm{CaCl}_{2}$ dalam proses pemurnian serbuk talk. Hasil percobaan menunjukkan bahwa proses pelarutan dengan asam klorida merupakan salah satu teknik pendekatan yang layak untuk memanfaatkan secara efisien sumber bijih karbonat kadar rendah. Dalam kesimpulannya menyatakan bahwa proses pelarutannya dapat mengurangi proses kalsinasi dolomit sehingga dapat menghemat banyak energi. Keunggulan proses pelarutan lainnya berupa proses produksi yang bersih berupa jalur proses yang ramah lingkungan untuk pemisahan $\mathrm{MgO}$ dan $\mathrm{CaCO}_{3}$ dari bijih dolomit-talk (Li, Li dan Ma, 2013).

Di Indonesia, proses pelarutan dolomit telah dilakukan dengan menggunakan asam klorida (Royani, 2016). Hasil penelitiannya 
menunjukkan bahwa konsentrasi larutan asam klorida dan temperatur sangat berpengaruh terhadap magnesium dan kalsium yang terekstrak. Efisiensi proses pelarutan dolomit masih sangat rendah yakni $60,31 \%$ pada temperatur $30{ }^{\circ} \mathrm{C}$ dengan konsentrasi $4 \quad \mathrm{~N} \mathrm{HCl}$ sehingga masih diperlukan penelitian lebih lanjut untuk mendapatkan parameter optimum.

Dari serangkaian beberapa penelitian dan potensi dolomit di Indonesia, sangat dimungkinkan untuk memproses bijih dolomit lokal melalui jalur pelarutan. Proses pelarutan memegang peranan penting dalam pengolahan dolomit supaya dapat digunakan dalam berbagai macam aplikasi. Banyak faktor yang mempengaruhi proses pelarutan di antaranya konsentrasi, suhu, ukuran partikel dan rasio cairan terhadap padatan. Pada penelitian ini, dilakukan proses pengolahan dolomit menggunakan larutan asam klorida yang terlebih dahulu dikalsinasi untuk mengekstrak logam kalsium. Tujuan penelitian untuk mendapatkan kondisi optimum pada proses pelarutan dolomit dalam mengekstrak kalsium. Parameter yang diamati meliputi pengaruh kecepatan pengadukan, konsentrasi asam, suhu proses dan persen padatan terhadap kalsium yang terekstrak. Dengan mengetahui pengaruh dari parameter-parameter tersebut diharapkan dapat memberi gambaran dalam upaya pemanfaatan sumber daya mineral lokal khususnya mineral dolomit supaya dapat dimanfaatkan dalam berbagai macam industri.

\section{METODE}

\section{Bahan dan Alat}

Bahan yang digunakan dalam percobaan proses pelarutan ini berupa serbuk bijih dolomit dari daerah Jawa Timur dan $\mathrm{HCl}$ p.a sebagai reagen pelarutan. Komposisi kimia serbuk dolomit ditunjukkan pada Tabel 1 dengan pola difraksi sinar-X seperti pada Gambar 1.

Tabel 1. Analisis komposisi kimia dolomit dengan XRF

\begin{tabular}{cccccccccc}
\hline Senyawa & $\mathrm{CaO}$ & $\mathrm{MgO}$ & $\mathrm{Na}_{2} \mathrm{O}$ & $\mathrm{SiO}_{2}$ & $\mathrm{Al}_{2} \mathrm{O}_{3}$ & $\mathrm{P}_{2} \mathrm{O}_{5}$ & $\mathrm{SO}_{3}$ & $\mathrm{~K}_{2} \mathrm{O}$ & $\mathrm{Fe}_{2} \mathrm{O}_{3}$ \\
\hline$\%$ Berat & 61,38 & 25,73 & 7,93 & 1,19 & 0,84 & 0,54 & 0,41 & 0,40 & 0,37 \\
\hline
\end{tabular}

Sumber: Royani, Sulistiyono dan Sufiandi (2016).

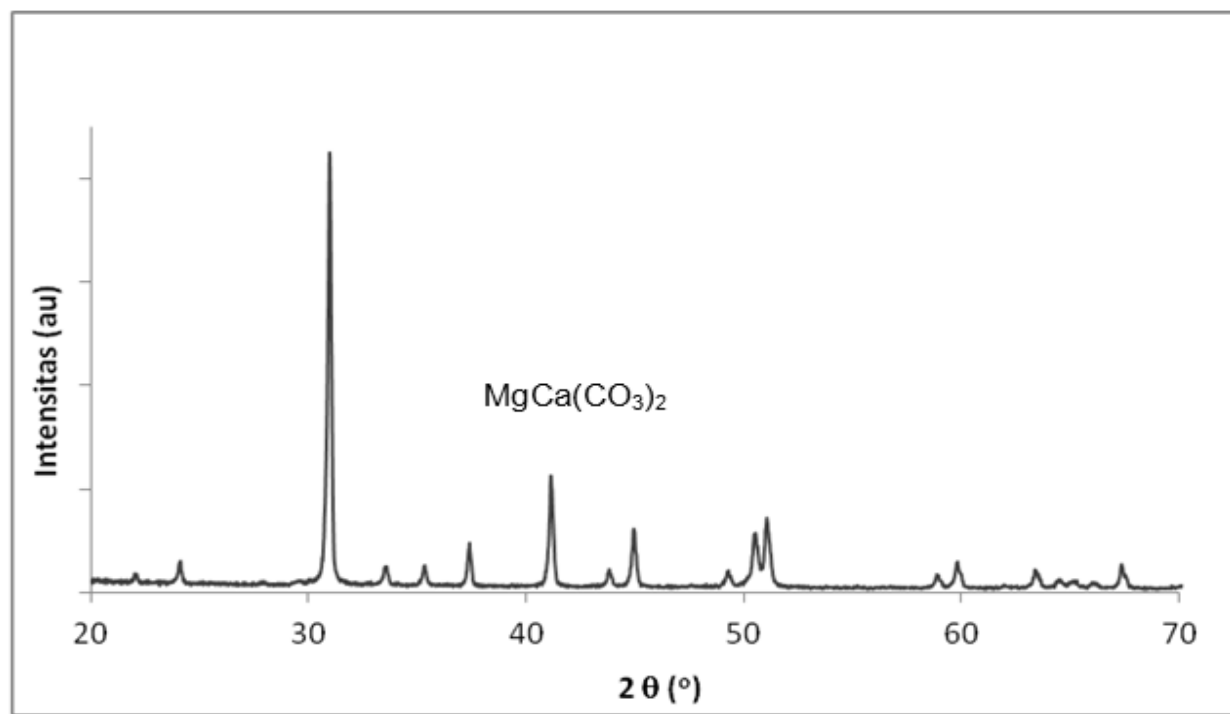

Sumber: Royani, Sulistiyono dan Sufiandi (2016)

Gambar 1. Pola difaksi sinar-X dolomit. 
Peralatan yang digunakan dalam percobaan ini meliputi disc mill untuk menghaluskan bijih dolomit, tungku muffle furnace (Carbolite-CWF 1300, England) digunakan untuk memanggang bijih dolomit, beaker gelas berkapasitas $1000 \mathrm{~mL}$ yang dimodifikasi sebagai reaktor proses pelarutan (gambar skematik pada Gambar 2). Eksperimen proses pelarutan dolomit dilakukan di laboratorium hidrometalurgi, Pusat Penelitian Metalurgi dan Material - LIPI.

Karakterisasi percontoh dolomit menggunakan difraksi sinar - X (Shimadzu XRD 7000) untuk analisis fasa dan menggunakan XRF untuk komposisi kimia. Sedangkan analisis percontoh dolomit terkalsinasi dan hasil pelarutan menggunakan ICP-OES (series 700). Scanning Electron Microscope (SEM) JEOL JSM-6390A digunakan untuk analisis struktur mikro dan morfologi butiran.

\section{Prosedur Percobaan}

Sebelum proses pelarutan, bijih dolomit dikeringkan, kemudian dihaluskan dengan disc mill sehingga diperoleh ukuran yang homogen di bawah 200 mesh (74 $\mu \mathrm{m})$. Kemudian dilakukan pemanggangan di dalam tungku pembakaran pada suhu $900{ }^{\circ} \mathrm{C}$ selama 5 jam. Proses pemanggangan dilakukan untuk mengubah fasa dolomit menjadi $\mathrm{MgO}$ dan $\mathrm{CaO}$ sehingga mudah dipisahkan (Royani, Sulistiyono dan Sufiandi, 2016). Selanjutnya dilakukan proses pelarutan dengan asam klorida menggunakan reaktor beaker gelas. Percobaan pelarutan dilakukan dengan memvariasikan parameter kecepatan pengadukan, konsentrasi asam, suhu proses dan rasio padatan terhadap larutan untuk setiap waktu proses 0,$5 ; 1 ; 2 ; 3 ; 4$ dan 5 jam. Sebanyak $500 \mathrm{~mL}$ larutan $\mathrm{HCl}$ dimasukkan ke dalam reaktor beaker gelas dan suhu proses disetting kemudian tekan tombol ON pada panel kontrol. Setelah suhu proses dicapai, percontoh dolomit dimasukkan dan batang pengaduk dijalankan selama waktu proses pelarutan. Setelah proses pelarutan pada waktu tertentu sejumlah larutan diambil dengan menggunakan pipet sebanyak $5 \mathrm{~mL}$ kemudian disaring. Larutan yang telah diambil kemudian diencerkan dan dianalisis menggunakan ICP-OES untuk mengetahui konsentrasi kalsium yang terekstrak.

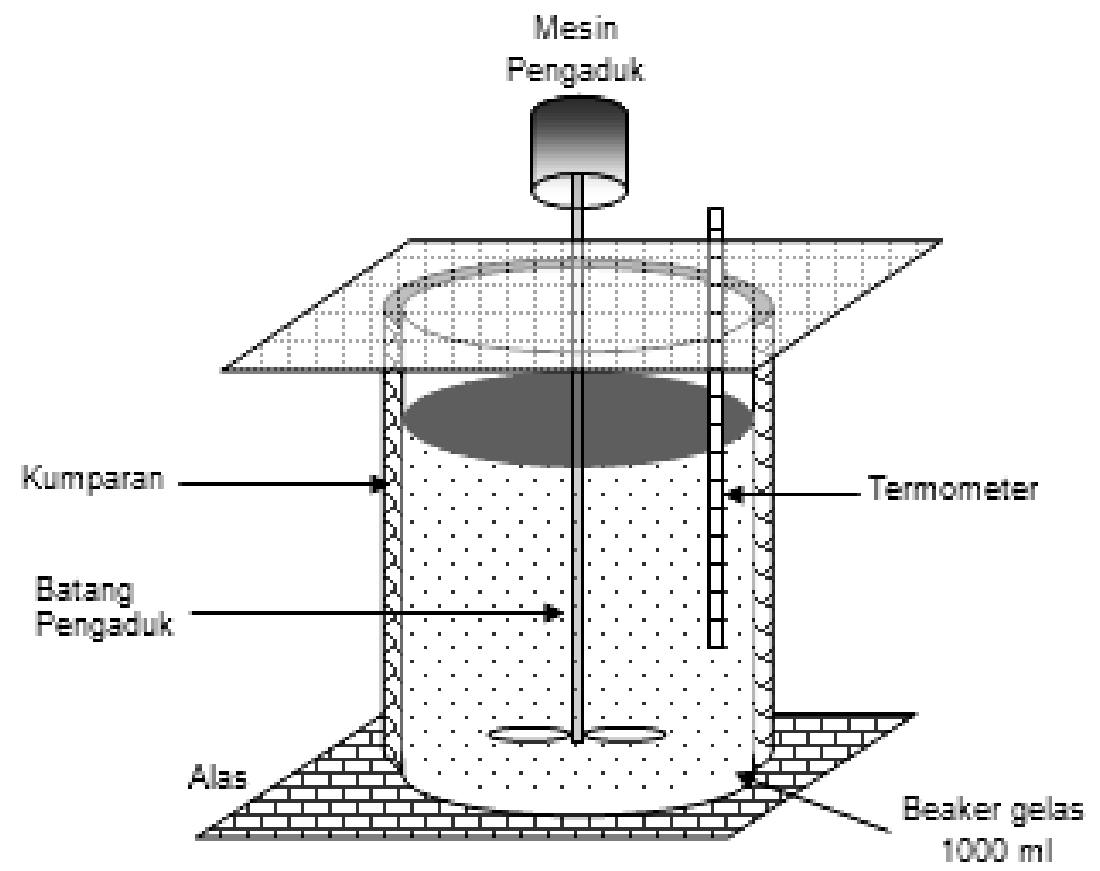

Sumber: Royani, Subagja and Manaf (2017)

Gambar 2. Skematik alat pelarutan 


\section{HASIL DAN PEMBAHASAN}

\section{Karakteristik Dolomit}

Dolomit yang digunakan dari daerah Jawa Timur mempunyai komponen utama $\mathrm{CaO}$ dan $\mathrm{MgO}$ masing-masing sebesar $61,38 \%$ dan $25,73 \%$ serta unsur pengotor lainnya seperti tersaji dalam Tabel 1. Adapun hasil analisis komposisi kimia dolomit setelah proses pemanggangan dengan ICP-OES mengandung $32,62 \%$ Ca dan 16,76 \% Mg atau dalam bentuk oksidanya sebesar $45,67 \% \mathrm{CaO}$ dan $27,79 \% \mathrm{MgO}$. Terjadi perubahan komposisi setelah pemanggangan dikarenakan sifatnya yang hidrokopis sehingga mudah bereaksi dengan lingkungan. Pada analisis dolomit awal dengan menggunakan difraksi sinar-X (Gambar 1), terlihat sangat jelas bahwa puncak-puncak menunjukkan mineral dolomit dan tidak ditemukan puncak/peak unsur-unsur pengotor dikarenakan kandungannya yang kecil. Hasil SEM-Mapping dolomit ditunjukkan pada Gambar 3, dapat dilihat bahwa sebaran unsur $\mathrm{Ca}, \mathrm{Mg}$, $\mathrm{O}$ serta $\mathrm{C}$ hampir merata dan berada pada seluruh permukaan yang menyatakan mineral dolomit.
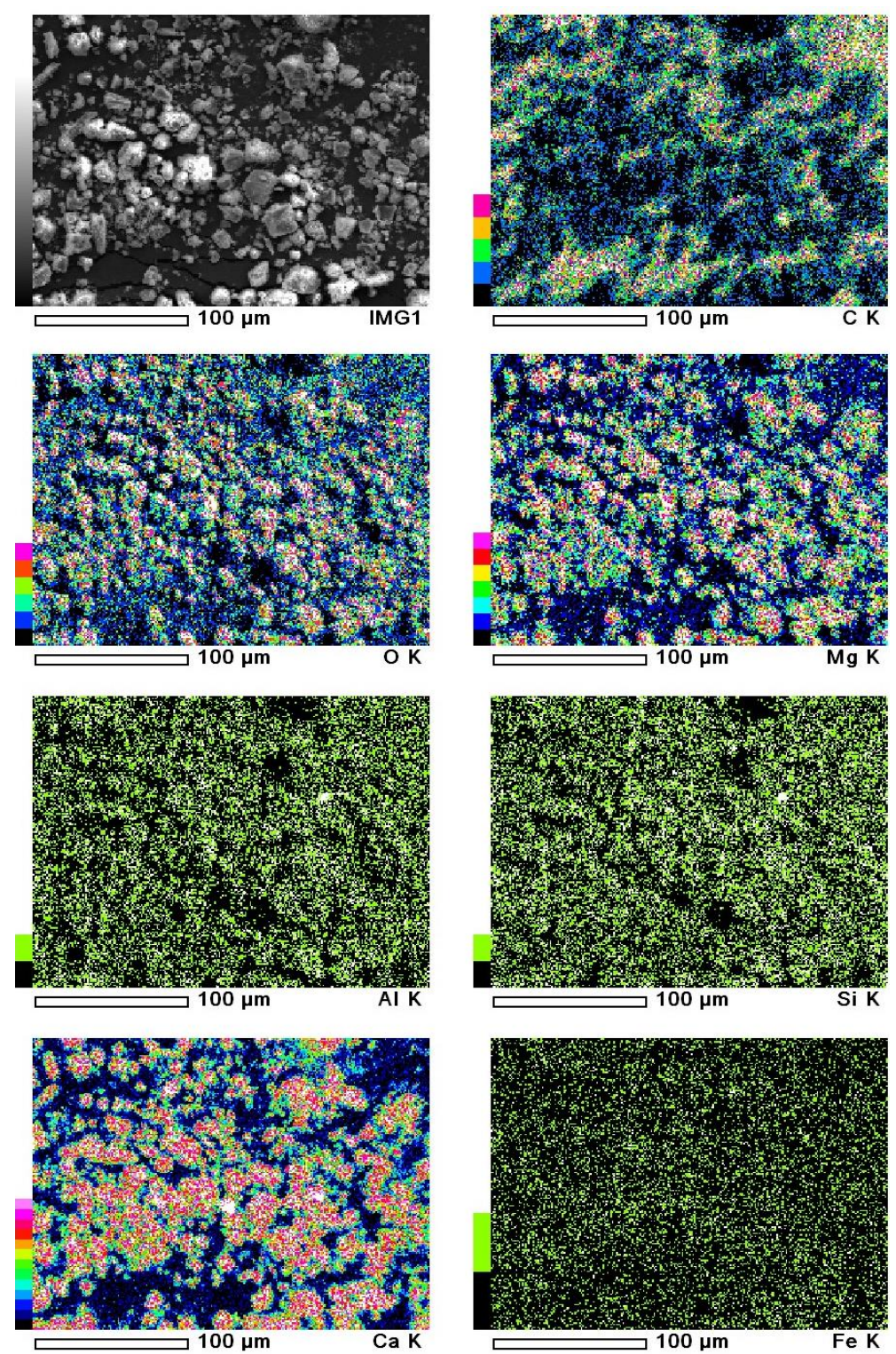

Sumber: Royani, Sulistiyono dan Sufiandi (2016)

Gambar 3. Hasil SEM-Mapping dolomit. 


\section{Proses Pelarutan}

Proses pelarutan dolomit terkalsinasi dengan larutan asam klorida mengikuti persamaan reaksi:

$\mathrm{CaCO}_{3} \cdot \mathrm{MgCO}_{3}+4 \mathrm{HCl}+\mathrm{H}_{2} \mathrm{O} \rightarrow \mathrm{CaCl}_{2}+$

$\mathrm{MgCl}_{2}+3 \mathrm{H}_{2} \mathrm{O}+2 \mathrm{CO}_{2}$

Faktor utama yang mempengaruhi proses pelarutan adalah kecepatan pengadukan, suhu reaksi, waktu reaksi dan rasio cair/padat.

\section{Pengaruh Kecepatan Pengadukan}

Pengaruh kecepatan pengadukan dilakukan untuk mengetahui kestabilan kalsium yang terekstrak. Percobaan dilakukan pada kecepatan pengadukan 200, 300, 400 dan $500 \mathrm{rpm}$ (rotasi per menit) dengan $1 \mathrm{M} \mathrm{HCl}$, suhu $30{ }^{\circ} \mathrm{C}$ dan rasio cairan/padatan sebesar 10:1 mL/g. Hasil percobaan pengaruh kecepatan pengadukan terhadap kalsium yang terekstrak ditunjukkan pada Gambar 4.

Terlihat bahwa terjadi peningkatan efisiensi pelarutan jika kecepatan putaran dinaikkan dari 200 hingga 500 rpm pada waktu 0,5 jam. Namun demikian, pada proses yang lebih lama kalsium yang terekstrak relatif stabil. Hasil percobaan tersebut menunjukkan bahwa kecepatan pengadukan tidak berpengaruh signifikan terhadap logam kalsium yang terekstrak. Hal ini terjadi karena proses pelarutan dolomit dikendalikan oleh reaksi kimia, sehingga proses pengadukan tidak berpengaruh secara signifikan (Bayrak, Laçin dan Saraç, 2010; Raza dkk., 2015). Hasil dari kecepatan pengadukan 400 rpm dan $500 \mathrm{rpm}$ relatif sama, baik pada waktu proses 0,5 jam maupun pada waktu proses 1 hingga 5 jam. Hasil tertinggi hanya sebesar 43,65 \% didapat pada 500 rpm selama 5 jam. Berdasarkan hasil percobaan ini, maka percobaan selanjutnya kecepatan pengadukan yang digunakan adalah 400 rpm.

\section{Pengaruh Konsentrasi}

Perlarutan untuk mengetahui pengaruh konsentrasi asam dilakukan dengan konsentrasi 0,$5 ; 1 ; 1,5$ dan $2 \mathrm{M} \mathrm{HCl}$ pada suhu $30{ }^{\circ} \mathrm{C}, 400 \mathrm{rpm}$ dan rasio cairan/padatan sebesar 10:1 mL/g. Hasil pengaruh konsentrasi terhadap kalsium yang terekstrak disajikan dalam Gambar 5.

Dari Gambar 5 tersebut, dapat dilihat bahwa peningkatan konsentrasi dari $0,5 \mathrm{M} \mathrm{HCl}$ ke 2 $M \mathrm{HCl}$ mampu meningkatkan efisiensi kalsium yang terekstrak dari 27,62 \% menjadi $51,78 \%$ selama waktu proses 0,5 jam dan dari 29,25\% menjadi 65,21 \% selama 3 jam. Peningkatan efisiensi kalsium yang terekstrak disebabkan karena semakin banyaknya ionion $\mathrm{H}^{+}$yang bereaksi pada konsentrasi yang lebih besar. Hasil ini sesuai dengan hasil penelitian pelarutan dolomit sebelumnya (Royani, 2016). Hasil yang sama juga didapat pada pelarutan dolomit dari Nigeria (Baba $d k k ., 2014)$. Hasil pelarutan dolomit Nigeria yang dilakukan dengan variasi konsentrasi $\mathrm{HCl}$ sebesar $0,1 \mathrm{~mol} / \mathrm{L}$ sampai $4 \mathrm{~mol} / \mathrm{L}$ menyatakan bahwa laju reaksi pelarutan dolomit meningkat seiring dengan bertambahnya konsentrasi HCl. Di samping itu, dalam penelitiannya juga mencatat bahwa laju pelarutan dolomit menurun pada konsentrasi $\mathrm{HCl}$ sebesar $4 \mathrm{~mol} / \mathrm{L}$ (Baba $d k k$., 2014). Laju reaksi pelarutan magnesit meningkat dengan peningkatan konsentrasi asam sampai 1,25 $M$ dan menurun jika konsentrasi melebihi 1,25 M (Bayrak, Laçin dan Saraç, 2010). Pada waktu proses selama 5 jam efisiensi kalsium terekstrak dicapai sebesar 31,82 dan 61,96 \% untuk masingmasing $0,5 \mathrm{M} \mathrm{HCl}$ dan $2 \mathrm{M} \mathrm{HCl}$. Dapat dilihat bahwa terjadi penurunan efisiensi kalsium terekstrak pada konsentrasi $2 \mathrm{M} \mathrm{HCl}$ jika waktu proses semakin lama. Penurunan efisiensi kalsium terekstrak pada konsentrasi yang tinggi seiring dengan lamanya waktu proses disebabkan karena terbentuknya lapisan pada permukaan partikel yang mengakibatkan penurunan laju reaksi pelarutan dolomit (Raza $d k k ., 2015)$.

\section{Pengaruh Suhu}

Setelah mengamati pengaruh kecepatan pengadukan dan konsentrasi asam, selanjutnya dilakukan percobaan pengaruh suhu. Untuk mempelajari pengaruh suhu tersebut, proses pelarutan dilakukan pada berbagai suhu $\left(30,45,60\right.$ dan $\left.75^{\circ} \mathrm{C}\right)$ dengan menggunakan konsetrasi asam $2 \mathrm{M} \mathrm{HCl}$, kecepatan pengadukan $400 \mathrm{rpm}$ dan rasio cairan/padatan sebesar 10:1 mL/g. 


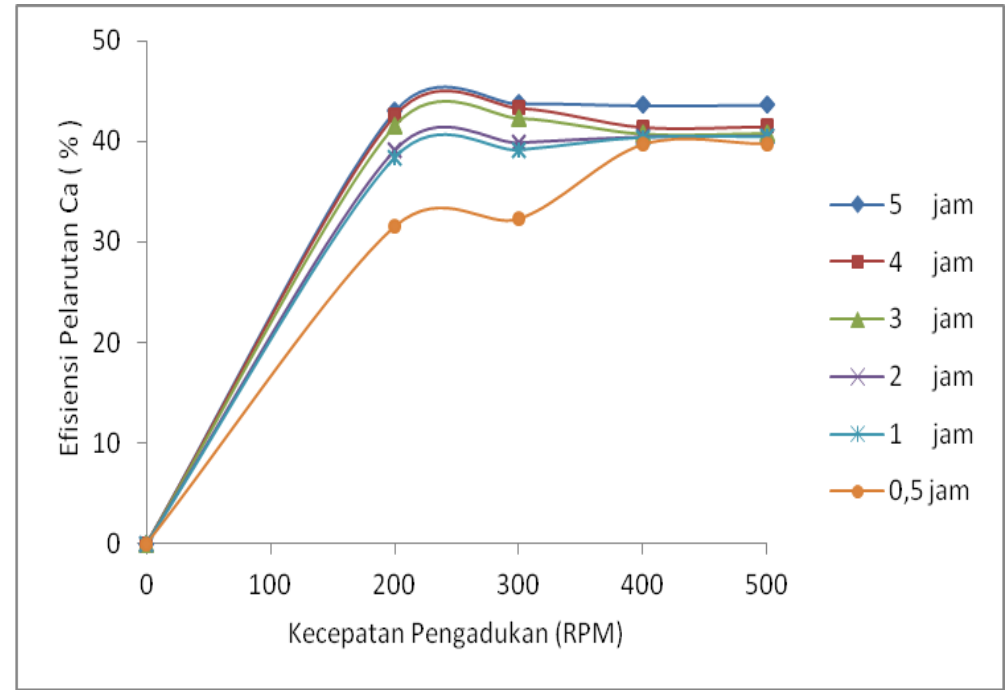

Gambar 4. Grafik pengaruh kecepatan pengadukan terhadap pelarutan Ca.

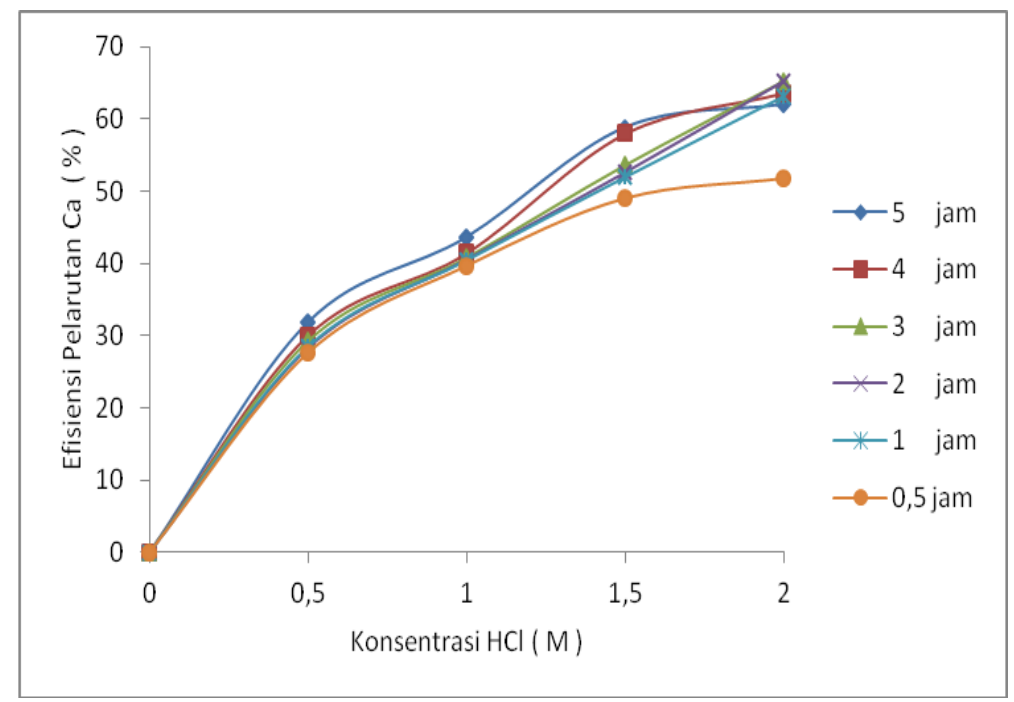

Gambar 5. Grafik pengaruh konsentrasi larutan $\mathrm{HCl}$ terhadap pelarutan Ca.

Hasil percobaan pengaruh suhu terhadap kalsium yang terekstrak ditunjukkan pada Gambar 6. Secara umum, dapat dilihat bahwa persen efisiensi kalsium yang terekstrak meningkat dengan naiknya suhu proses. Terlihat bahwa kenaikan suhu dari $30{ }^{\circ} \mathrm{C}$ ke $75{ }^{\circ} \mathrm{C}$ mampu meningkatkan efisiensi kalsium terekstrak dari $51,78 \%$ menjadi $75,21 \%$ pada waktu proses selama 0,5 jam. Hal ini karena reaksi proses pelarutan berjalan semakin cepat jika suhu dinaikkan sehingga kalsium yang terlarut semakin banyak. Efisiensi kalsium terekstrak meningkat dari $61,96 \%$ menjadi $87,12 \%$ dalam waktu proses selama 5 jam. Peningkatan signifikan kalsium terekstrak dikarenakan meningkatnya laju reaksi pelarutan dolomit dengan asam klorida pada suhu yang lebih tinggi. Peningkatan nilai efisiensi kalsium yang terekstrak juga bertambah sejalan dengan lamanya waktu proses pelarutan. Hasil ini sesuai dengan proses pelarutan dolomit yang berasal dari Nigeria dengan menggunakan larutan asam klorida (Baba dkk., 2014). Hasilnya menyatakan bahwa kelarutan dolomit meningkat jika suhu proses dinaikkan karena laju reaksi dikendalikan oleh proses reaksi kimia. 


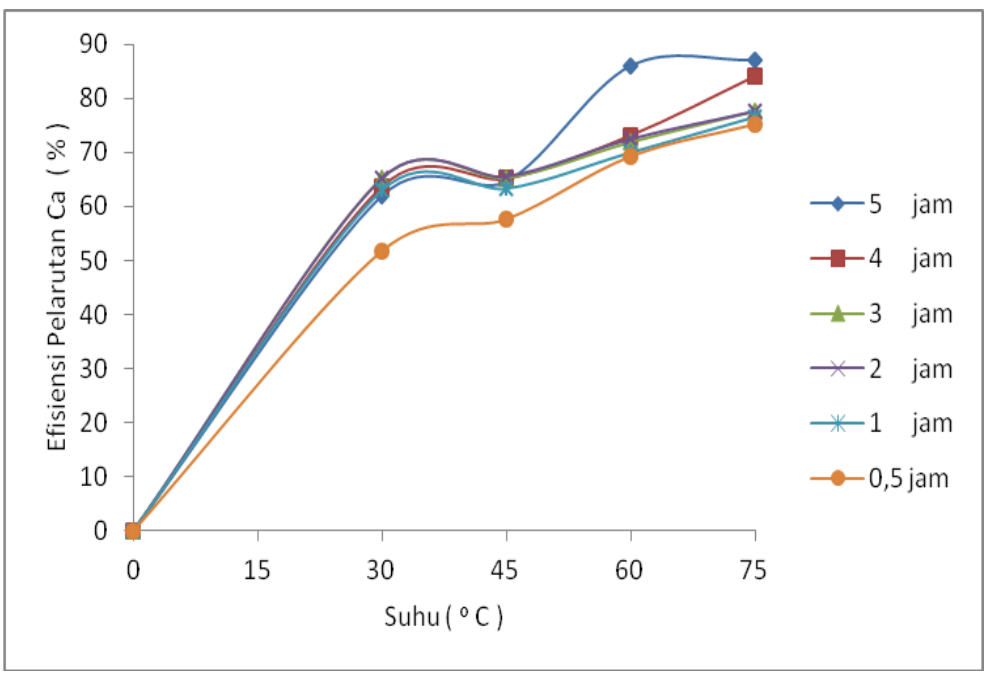

Gambar 6. Grafik pengaruh suhu proses terhadap pelarutan Ca.

\section{Pengaruh Rasio Cairan/Padatan}

Dalam mengamati pengaruh rasio cairan terhadap padatan, rasio yang digunakan sebesar 5; 7; 10 dan $20 \mathrm{~mL} / \mathrm{g}$ yakni sebanyak 120; 86; 60 dan 30 gram dolomit dalam 600 $\mathrm{mL}$ larutan asam klorida. Percobaan dilakukan pada suhu $75{ }^{\circ} \mathrm{C}$ dengan larutan $2 \mathrm{M} \mathrm{HCl}$ dan kecepatan pengadukan sebesar $400 \mathrm{rpm}$. Hasil pengaruh rasio cairan/padatan terhadap efisiensi pelarutan kalsium yang terekstrak ditunjukkan dalam Gambar 7.
Dari Gambar 7 terlihat efisiensi kalsium terekstrak meningkat secara signifikan jika rasio cairan/padatan dinaikkan dari $5 \mathrm{~mL} / \mathrm{g}$ menjadi $20 \mathrm{~mL} / \mathrm{g}$. Pada rasio cairan/padatan sebesar $5 \mathrm{~mL} / \mathrm{g}$, efisiensi kalsium terekstrak diperoleh 37,$39 ; 37,63$ dan $37,70 \%$ untuk waktu proses masing-masing selama 0,$5 ; 2$; dan 4 jam. Sedangkan pada rasio cairan/padatan sebesar $20 \mathrm{~mL} / \mathrm{g}$, efisiensi kalsium terekstrak diperoleh sebesar 85,02; 91,20 dan $97,57 \%$ untuk waktu proses masing-masing selama 0,$5 ; 2$; dan 4 jam.

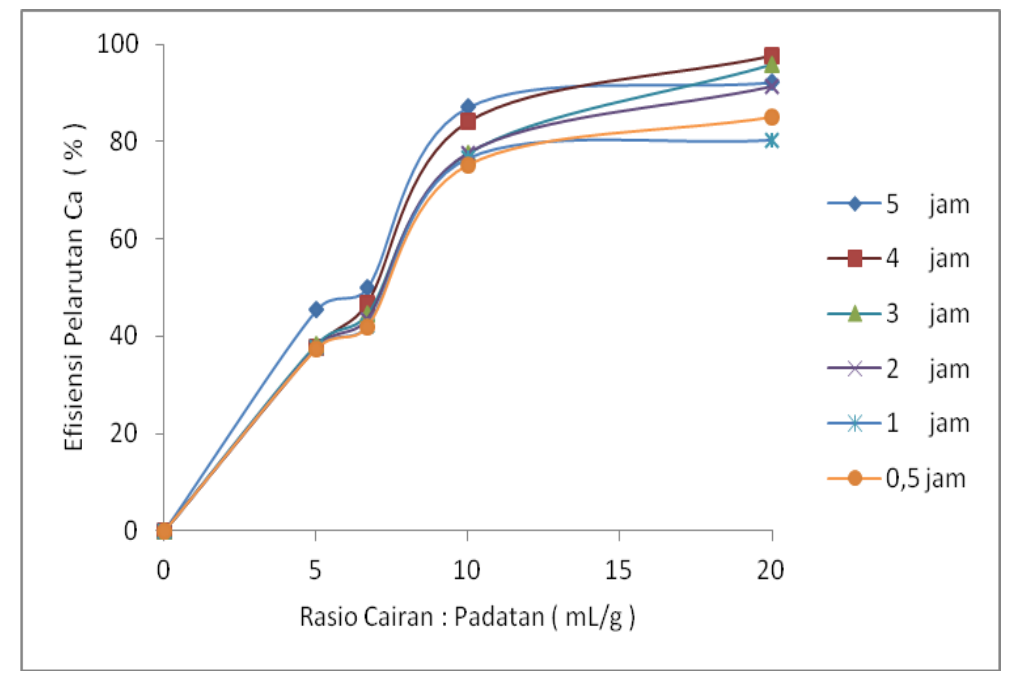

Gambar 7. Grafik pengaruh rasio cairan/padatan terhadap pelarutan Ca. 
Semakin banyak padatan yang digunakan maka efisiensi kalsium yang terekstrak semakin menurun. Penyebabnya karena pada padatan yang rendah, jumlah ion $\mathrm{H}^{+}$yang bereaksi lebih banyak dibandingkan pada padatan yang lebih tinggi dalam kondisi konsentrasi dan volume larutan yang sama. Selain itu, jika padatan yang digunakan lebih banyak, maka jumlah pengotor yang ikut bereaksi lebih banyak juga sehingga menyebabkan peningkatan kebutuhan asam. Hasil yang sama juga terjadi pada pelarutan bijih dolomit yang berasal dari Turki dengan menggunakan asam klorida (Abali, Bayca dan Vaizogullar, 2011). Hasil penelitiannya menunjukkan bahwa terjadi penurunan laju pelarutan bijih dolomit jika rasio perbandingan larutan/padatan menurun.

\section{KESIMPULAN DAN SARAN}

Pemanfaatan dolomit dapat dilakukan melalui proses pelarutan dengan asam klorida menghasilkan larutan kalsium klorida. Efisiensi kalsium terekstrak meningkat dengan penambahan konsentrasi asam, rasio cairan/padatan dan peningkatan suhu. Hasil optimum proses pelarutan dicapai pada suhu $75{ }^{\circ} \mathrm{C}$, konsetrasi larutan $2 \mathrm{M} \mathrm{HCl}$ dan kecepatan pengadukan $400 \mathrm{rpm}$ dengan efisiensi kalsium terekstrak sebesar 97,57 \%. Perlu dilakukan penelitian lebih lanjut mengenai proses pengendapan sehingga didapat padatan kalsium yang dapat diaplikasikan pada industri.

\section{UCAPAN TERIMA KASIH}

Penulis mengucapkan terimakasih kepada Pusat Penelitian Metalurgi dan Material, Lembaga Ilmu Pengetahuan Indonesia yang telah mendanai penelitian ini melalui kegiatan Kompetensi Inti.

\section{DAFTAR PUSTAKA}

Abali, Y., Bayca, S. U. and Vaizogullar, A. (2011) 'Optimization of dolomite ore leaching in hydrochloric acid solutions', Physicochemical Problems of Mineral Processing, 46(1), pp. 253-262. Available at:
http://www.journalssystem.com/ppmp/Optimi zation-of-dolomite-ore-leaching-inhydrochloric-acid-solutions, 79072,0,2.html.

Baba, A. A., Omipidan, A. O., Adekola, F. A., Job, O., Alabi, A. G. F., Baral, A. and Samal, R. (2014) 'Optimization study of a nigerian dolomite ore dissolution by hydrochloric acid', Journal of Chemical Technology and Metallurgy, 49(3), pp. 280-287. Available at: http://dl.uctm.edu/journal/node/j2014-3/10Baba-280-287.pdf.

Bayrak, B., Laçin, O. and Saraç, H. (2010) 'Kinetic study on the leaching of calcined magnesite in gluconic acid solutions', Journal of Industrial and Engineering Chemistry, 16(3), pp. 479484. doi: 10.1016/j.jiec.2010.01.055.

Erskini (1996) 'Dolomit dan kegunaannya', in Prosiding Konferensi Energi Sumberdaya Alam dan Lingkungan BPPT. Jakarta: BPPT, pp. 34-44.

Li, G., Li, Z. and Ma, H. (2013) 'Comprehensive use of dolomite-talc ore to prepare talc, nano-MgO and lightweight $\mathrm{CaCO} 3$ using an acid leaching method', Applied Clay Science, 86, pp. 145152. doi: 10.1016/j.clay.2013.09.015.

Mantilaka, M. M. M. G. P. G., Pitawala, H. M. T. G. A., Karunaratne, D. G. G. P. and Rajapakse, R. M. G. (2014) 'Nanocrystalline magnesium oxide from dolomite via poly(acrylate) stabilized magnesium hydroxide colloids', Colloids and Surfaces A: Physicochemical and Engineering Aspects, 443, pp. 201-208. doi: 10.1016/j.colsurfa.2013.11.020.

Mustafa, A. M. K., Al-Dahan, D. K. and Khachik, T. V. (2014) 'Laboratory wtudy of $\mathrm{MgO}$ preparation from Iraqi dolomite by leachprecipitation - Pyrohydrolysis process', Iraqi Bulletin of Geology and Mining, 10(3), pp. 83-107. Available at: https://ibgm.iraqjournals.com/article_96062.h tml.

Orosco, R. P., Ruiz, M. del C., Barbosa, L. I. and González, J. A. (2011) 'Purification of talcs by chlorination and leaching', International Journal of Mineral Processing, 101(1-4), pp. 116-120. doi: 10.1016/j.minpro.2011.09.006.

Raza, N., Zafar, Z. I. and Najam-ul-Haq (2013) 'An analytical model approach for the dissolution kinetics of magnesite ore using ascorbic acid as leaching agent', International Journal of Metals, 2013, pp. 1-6. doi: 10.1155/2013/352496. 
Raza, N., Zafar, Z. I., Najam-ul-Haq and Kumar, R. V. (2015) 'Leaching of natural magnesite ore in succinic acid solutions', International Journal of Mineral Processing, 139, pp. 25-30. doi: 10.1016/j.minpro.2015.04.008.

Raza, N., Zafar, Z. I. and Najam-ul-Haq, M. (2014) 'Utilization of formic acid solutions in leaching reaction kinetics of natural magnesite ores', Hydrometallurgy, 149, pp. 183-188. doi: 10.1016/j.hydromet.2014.08.008.

Royani, A. (2016) 'Proses pelarutan bijih dolomit dalam larutan asam klorida', in Prosiding SEMNASTEK. Jakarta: Universitas Muhammadiyah Jakarta, pp. TK006-1-TK006-5. Available at: https://jurnal.umj.ac.id/index.php/semnastek/ar ticle/view/711.
Royani, A., Subagja, R. and Manaf, A. (2017) 'Studi pelindian mangan secara reduksi dengan menggunakan larutan asam sulfat', Jurnal Riset Teknologi Industri, 11(1), pp. 1-9. doi: 10.26578/jrti.v11i1.1724.

Royani, A., Sulistiyono, E. and Sufiandi, D. (2016) 'Pengaruh suhu kalsinasi pada proses dekomposisi dolomit', Jurnal Sains Materi Indonesia, 18(1), pp. 41-46. doi: 10.17146/jsmi.2016.18.1.4186.

Xie, J., Chen, T., Xing, B., Liu, H., Xie, Q., Li, H. and $\mathrm{Wu}, \mathrm{Y}$. (2016) 'The thermochemical activity of dolomite occurred in dolomitepalygorskite', Applied Clay Science, 119, pp. 42-48. doi: 10.1016/j.clay.2015.07.014. 